\title{
Pengaruh Physical Evidence Terhadap Keputusan Pembelian Konsumen Di Happy Cow Palasari Bandung (Survey pada Konsumen Di Happy Cow Palasari Bandung)
}

\section{Physical Evidence Influence towards Consumers Purchasing Decision in Happy Cow Palasari Bandung" (Survey on Happy Cow Palasari Bandung Consumer)}

\author{
Tinka Sabrilia, Rini Andari, Taufik Abdullah \\ Program Studi Manajemen Industri Katering \\ Fakultas Pendidikan Ilmu Pengetahuan Sosial \\ Universitas Pendidikan Indonesia
}

\begin{abstract}
Tourism has become one of the largest industries in the world, and are the mainstay in generating foreign exchange in many countries, including Indonesia with a very vast natural wealth. In a world traveler tourism industry can not be separated from tourism accommodation ranging from lodging services, transport and restaurants. Which at this present moment tourism is much discussed is culinary, talk about the culinary is a city rich in culinary. One of the restaurants in the city of Bandung, Happy Cow Steak Palasari Bandung is located in Jalan Palasari No. 30, Bandung. With the passage of time and an increasingly tight competition in restaurant sales decreased. It is seen from the sales data Happy Cow Steak Palasari Bandung has decreased the number of consumers in 2015 amounted to 15.3\%.One of the strategies used to increase the return of consumer purchasing decisions, namely physical evidence. Increased physical evidence aimed to withdraw the interest of consumers to make purchases at the Happy Cow Steak Palasari Bandung.

The object in this research is that consumers in Happy Cow Steak Palasari Bandung. The independent variable in this study is physical evidence and the dependent variable is buying decision. This study uses descriptive and verification method, with explanatory survey method. The number of samples in this study of 100 respondents. Data analysis technique used is the technique of multiple regression analysis with the program.

Based on the results of studies found that physical evidence has a positive influence on purchasing decisions with that middle relationship categories.

Keywords: Physical Evidence, Purchasing Decisions
\end{abstract}

\begin{abstract}
ABSTRAK
Pariwisata telah menjadi salah satu industri terbesar di dunia, dan merupakan andalan utama dalam meningkatkan pendapatan negara termasuk di Indonesia. Dalam dunia industri pariwisata wisatawan tidak lepas dari akomodasi pariwisata mulai dari jasa penginapan, transportasi dan restoran. Dimana pada saat sekarang ini pariwisata yang banyak di perbincangkan adalah kuliner, berbicara tentang kuliner Bandung merupakan salah satu kota yang kaya akan kuliner. Salah satu restoran yang ada di kota Bandung yaitu Happy Cow Steak Palasari Bandung yang berada di
\end{abstract}


Jalan Palasari No. 30, Bandung. Seiring dengan waktu dan persaingan yang makin ketat, penjualan di restoran ini menurun. Dilihat dari data penjualan Happy Cow Steak Palasari Bandung mengalami penurunan jumlah konsumen pada tahun 2015 sebesar $15,3 \%$. Salah satu strategi yang digunakan untuk meningkatkan kembali keputusan pembelian konsumen yaitu physical evidence. Peningkatan physical evidence bertujuan untuk menarik kembali minat konsumen untuk melakukan pembelian di Happy Cow Steak Palasari Bandung.

Objek pada penelitian ini adalah konsumen di Happy Cow Steak Palasari Bandung. Variabel bebas pada penelitian ini yaitu physical evidence dan variabel terikatnya yaitu Keputusan Pembelian. Penelitian ini menggunakan metode deskriptif dan verifikatif, dengan metode explanatory survey. Jumlah sampel pada penelitian ini 100 responden. Sedangkan teknik analisis data yang digunakan adalah teknik analisis regresi berganda dengan program SPSS 22.

Berdasarkan hasil Penelitian ditemukan bahwa physical evidence memiliki pengaruh yang positif terhadap keputusan pembelian dengan kategori hubungan yang sedang.

Kata Kunci: Physical Evidence, Keputusan Pembelian

\section{Latar belakang masalah}

\section{PENDAHULUAN}

Salah satu restoran yang ada di bandung yaitu Happy Cow Steak Palasari Bandung yang berada di Jalan Palasari No. 30, Bandung. Happy Cow Steak merupakan restoran yang menyediakan berbagai macam menu. Bangunan restoran ini unik dengan tema interior dari kayu. restoran ini salah satu banyaknya tempat kuliner yang berada dikota bandung yang menjadi tujuan kuliner. Dengan seiiringnya waktu dan persaingan yang makin ketat penjualan di restoran ini menurun. Berdasarkan hasil wawancara dengan management Happy Cow Steak diketahui adanya penurunan penjualan dapat dilihat pada Tabel 1.2 tentang data konsumen Happy Cow Steak Palasari Bandung

Tabel

Data Jumlah Konsumen dan Omset Happy Cow Steak Palasari Bandung Tahun 2013-2915

\begin{tabular}{|c|c|c|c|}
\hline Tahun & 2013 & 2014 & $\mathbf{2 0 1 5}$ \\
\hline $\begin{array}{c}\text { Total } \\
\text { Konsumen }\end{array}$ & $\mathbf{6 1 2 2}$ & $\mathbf{6 1 0 5}$ & $\mathbf{6 0 8 0}$ \\
\hline $\begin{array}{c}\text { Total } \\
\text { omset }\end{array}$ & $\begin{array}{c}\text { Rp } \\
\mathbf{6 5 0 . 7 3 8 . 2 0 0}\end{array}$ & $\begin{array}{c}\text { Rp } \\
\mathbf{5 9 1 . 5 6 2 . 0 0 0}\end{array}$ & $\begin{array}{c}\text { Rp } \\
\mathbf{5 1 3 . 8 4 9 . 7 0 0}\end{array}$ \\
\hline
\end{tabular}

Sumber: Owner happy cow steak 2015

Tabel 1.1 menunjukan jumlah konsumen di Happy Cow Steak Palasari Bandung mengalami penurunan dapat dilihat dari total kunjungan tahun 2013 yaitu 6122 orang dan mengalami penurunan pada tahun 2014 sebesar 10,4\% yaitu sebanyak 6105 orang dan mengalami penurunan kembali 2015 sebesar 15,3\% yaitu 6080 orang. Selain itu dapat di lihat juga dari total omset pertahun pada tahun 2013 yaitu Rp 650.738.200 dan mengalami penurunan pada tahun 2014 sebesar 9\% yaitu 
Rp 591.562.200 dan mengalami penurunan kembali pada tahun 2015 sebesar 13\% yaitu Rp 513.849.700, sedangkan manajemen Happy Cow Steak Palasari Bandung memiliki target omset akan meningkat tiap tahunnya sebesar $30 \%$ namun kenyataannya omset tidak memenuhu target malah mengalami penurunan. Selain data dari tabel 1.1 berdasarkan hasil wawancara dengan pihak management Happy Cow Steak Palasari Bandung rata-rata konsumen yang datang pada satu hari hanya $10 \%$ dari seating capacity yang berjumlah 100. . Selain itu di Happy Cow Steak Palasari Bandung terdapat hiasan tumbuhan yang sudah kering, pencahayaan yang kurang, warna cat yang sudah mulai pudar, dan tempat parkir yang kurang memadai. Berdasarkan hasil wawancara bahwa permasalahan yang di alami oleh Happy Cow Steak Palasari Bandung yaitu menurunnya keputusan pembelian dari konsumen.

Berdasarkan pernyataan diatas serta berdasarakan data yang penjualan di Happy Cow Steak Palasari Bandung yang diketahui mengalami penurunan jumlah penjualan, maka salah satu langkah strategi untuk meningkatkan penjualan yaitu dengan pengelolaan physical evidence di restoran itu sendiri, seperti perbaikan interior yang mulai usang, perawatan hiasan serta fasilitas penunjang dan kenyamanan area parkir, perawatan eksterior, serta menjaga keamanaan dan kebersihan area sekitar. Physical evidence di Happy Cow Steak Palasari Bandung lebih di tujukan kepada layout serta konsep restoran, hasil wawancara dengan Bapak Irfan selaku owner Happy Cow Steak Palasari Bandung di dapat informasi bahwa, aspek physical evidence di Happy Cow Steak Palasari Bandung secara umum masih belum optimal.

Oleh karena itu physical Evidence (bukti fisik) sangat penting dalam image atau persepsi karena melalui bukti fisik ini konsumen siap untuk mengidentifikasikan dan

membandingkan suatu perusahaan jasa dengan perusahaan jasa lainnya sehingga dalam pengambilan keputusan penggunaan jasa konsumen tidak salah pilih. Dalam penelitiannya Merwe (2006, hlm. 67) menyebutkan "Jasa pariwisata pada dasarnya tidak berwujud, sehingga pelanggan sering mengandalkan bukti fisik di lingkungan layanan untuk mengevaluasi kualitas layanan. Lingkungan fisik juga dapat mempengaruhi pilihan pelanggan, harapan, perilaku pembelian dan kepuasan dengan organisasi pariwisata". Berdasarkan data permasalahan di atas yang sedikit telah dipaparkan, maka dari itu Penulis tertarik untuk melakukan penelitian tentang permasalahan tersebut yang berjudul " Pengaruh Physical Evidence Terhadap Keputusan Pembelian Konsumen Di Happy Cow Steak Palasari Bandung “ 2. Rumusan masalah

Adapun Rumusan Masalah yang menjadi bahasan penelitian ini lebih ditekankan terhadap:

a. Bagaimana gambaran Physical evidence yang terdiri facility interior, facility eksterior, dan other tangibles di Happy Cow Steak Palasari Bandung.

b. Bagaimana gambaran keputusan pembelian di Happy Cow Steak Palasari Bandung. Seberapa besar pengaruh physical evidence

c. erhadap keputusan pembelian di Happy Cow Steak Palasari Bandung.

TINJAUAN PUSTAKA, KERANGKA PEMIKIRAN, DAN HIPOTESIS

\section{Konsep Bauran pemasaran}


Menurut Tjiptono (2006, hlm. 30) Konsep bauran pemasaran di populerkan pertama kali beberapa dekade yang lalu oleh Jerome Mc.Carthy yang merumuskannya menjadi 4P (Product, price, promotion, dan place). Bila di tinjau dari sudut pandang pelanggan, 4P bisa di rumuskan menjadi 4C (customers' need and wants, cost, communication, and convenience). Dalam perkembangannya, sejumlah penelitian menunjukan bahwa penerapam 4P terlampau terbatas/ sempit untuk bisnis jasa karena beberapa alasan. Hasilnya 4P tradisional diperluas dan ditambakan dengan empat unsur lainnya, yaitu people, process, physical evidence, dan customer service.

\section{Konsep Physical Evidence}

Tabel 2.1

Definisi Physical Evidence Berdasarkan Pendapat Beberapa Ahli

\begin{tabular}{|l|l|}
\hline Ratih (2008, hlm. 64) & $\begin{array}{l}\text { Sesuatu hal yang secara nyata turut } \\
\text { mempengaruhi keputusan konsumen } \\
\text { untuk membeli dan menggunakan } \\
\text { produk jasa yang ditawarkan. }\end{array}$ \\
\hline Yazid (2008, hlm. 20) & $\begin{array}{l}\text { Lingkungan fisik adalah di mana jasa } \\
\text { disampaikan dan dimana perusahaan } \\
\text { dan konsumennya berinteraksi serta } \\
\text { setiap komponen tangible memfasilitasi } \\
\text { penampilan atau komunikasi jasa } \\
\text { tersebut. }\end{array}$ \\
\hline Murdiono (2006, hlm. 30 & $\begin{array}{l}\text { Bukti fisik merupakan tersedianya } \\
\text { fasilitas fisik, perlengkapan, dan sarana } \\
\text { komunikasi serta yang lainnya yang } \\
\text { dapat dan harus ada dalam proses jasa. }\end{array}$ \\
\hline
\end{tabular}

Sumber : Dari berbagai literatur

Sarana fisik merupakan hal yang secara nyata turut mempengaruhi keputusan konsumen untuk membeli dan menggunakan produk jasa yang ditawarkan. Unsur unsur yang termasuk dalam sarana fisik adalah lingkungsn fisik, bangunan fisik, peralatan, logo, warna dan barang - barang lainnya.

Zeithaml, Bitner and Gremler (2013, hlm. 278) menyebutkan bahwa dimensi dari bukti fisik terdapat pada tabel di bawah :

Tabel Dimensi Physical Evidence

\begin{tabular}{|c|}
\hline Facility Exterior \\
- Exterior design \\
- Signage \\
- Parking \\
- Landscape \\
- Surounding environment \\
Facility Interior \\
- Interior design \\
- Equipment \\
- Signage \\
\hline
\end{tabular}




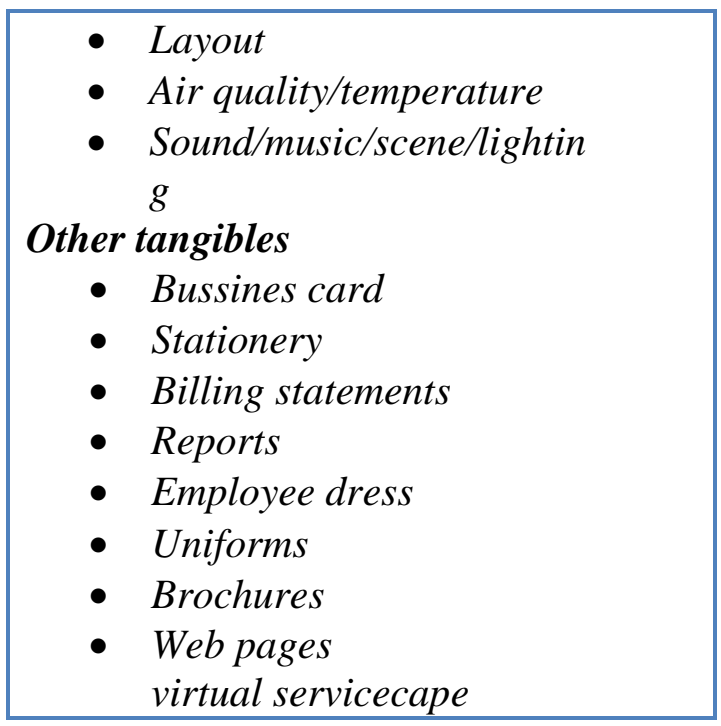

Sumber : Zeithaml, Bitner and Gremler (2013, hlm. 278).

\section{Konsep Keputusan Pembelian}

Keputusan pembelian menurut Schiffman, Kanuk (2004, hlm. 547) adalah pemilihan dari dua atau lebih alternatif pilihan keputusan pembelian, artinya bahwa seseorang dapat membuat keputusan, haruslah tersedia beberapa alternatif pilihan. Keputusan untuk membeli dapat mengarah kepada bagaimana proses dalam pengambilan keputusan tersebut itu dilakukan.

Menurut Kotler dan amstrong (2008, hlm. 146) keputusan pembelian terdiri dari enam dimensi, yaitu :

1. Pemilihan produk

2. Pemilihan merek

3. Pemilihan penyalur

4. Pemilihan waktu pembelian

5. Pemilihan jumlah pembelian

6. Metode pembayaran

4. Kerangka Pemikiran

\author{
n
}

1. $\begin{aligned} & \text { Products } \\ & \text { 2. }\end{aligned}$

Pricing
Promotion

Place

People

6. Physical

evidence

Process

Customer

service

Fandy Tjiptono

(2006:31)

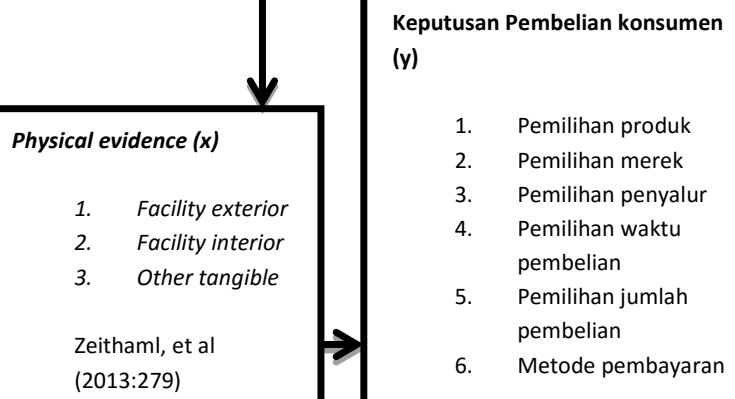

Keputusan Pembelian konsumen

(y)

Physical evidence (x)

1. Facility exterior

Facility interior

3. Other tangible

Zeithaml, et al

(2013:279) 
Keterangan : di Teliti $\square$ Tidak diteliti [-] pengaruh

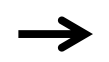

Gambar 2.1

Kerangka pemikiran

\section{Hipotesis}

hipotesis dalam penelitian ini dapat dirumuskan, terdapat pengaruh signifikan antara physical evidence terhadap keputusan pembelian. Sedangkan sub hipotesisnya adalah :

1. Terdapat pengaruh facility interior terhadap keputusan pembelian konsumen.

2. Terdapat pengaruh facility exterior terhadap keputusan pembelian konsumen.

3. Terdapat pengaruh other tangibles terhadap keputusan pembelian konsumen.

\section{Jenis Penelitian Yang Digunakan}

\section{METODE PENELITIAN}

Penelitian ini dilakukan bertujuan untuk menggambarkan objek penelitian dan juga menguji hubungan antar variabel serta menguji hipotesis, sehingga jenis penelitian yang di pakai dalam penelitian ini adalah metode deskriptif dan verifikatif. Menurut Sugiyono (2010, hal. 35) bahwa " Penelitian deskriptif adalah penelitian yang dilakukan untuk mengetahui keberadaan variabel mandiri, baik satu variabel atau lebih variable (variable yang berdiri sendiri) tanpa membuat perbandingan dan atau mencari hubugan variabel satu sama lain."

\section{Metode Penelitian yang digunakan}

Metode yang digunakan dalam penelitian ini adalah explanatory survey. Dalam Sugiyono (2010, hlm. 17) Kerlinger berpendapat bahwa "Metode survey adalah metode penelitian yang dilakukan pada populasi besar atau kecil, tetapi data yang dipelajari adalah data dari sample yang di ambil dari populasi tersebut, sehingga ditemukan kejadian-kejadian relatif, distribusi, dan hubungan-hubungan antara variabel sosiologis maupun psikologis."

Pada penelitian ini, explanatory survey dilakukan melalui kegiatan pengumpulan informasi dari sebagian populasi secara langsung di tempat kejadian (empirik) melalui kuesioner dengan tujuan untuk mengetahui pendapat sebagian populasi yang di teliti terhadap penelitian yang dilakukan.

\section{HASIL PENELITIAN}

\section{Pengujian Hipotesis Secara Simultan (Uji F)}

Untuk menguji signifikansi dapat digunakan uji $\mathrm{F}$, untuk lebih jelasnya mengenai output ANOVA dengan program SPSS dapat dilihat pada Tabel 4.26 berikut:

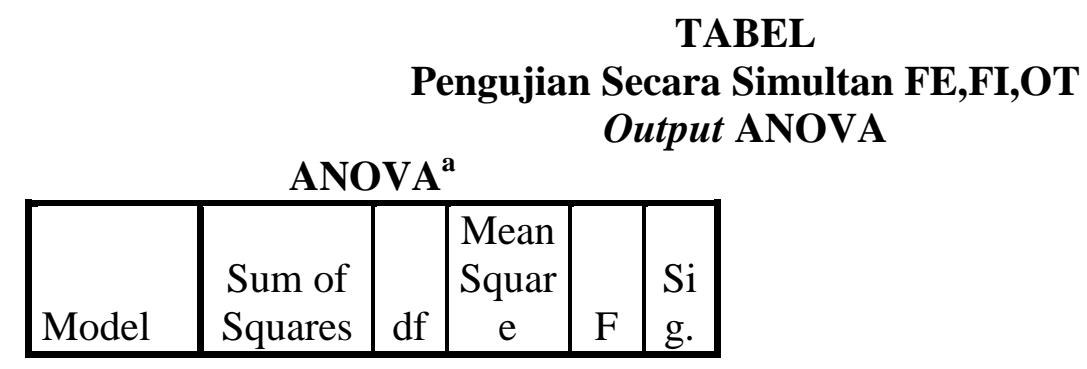




\begin{tabular}{|c|c|c|c|c|c|}
\hline $\begin{array}{c}1 \text { Regres } \\
\text { sion }\end{array}$ & 69,314 & 1 & $\begin{array}{r}69,31 \\
4\end{array}$ & $\begin{array}{r}4, \\
58 \\
8\end{array}$ & $\begin{array}{r}, 0 \\
35 \\
\mathrm{~b}\end{array}$ \\
\hline $\begin{array}{l}\text { Residu } \\
\text { al }\end{array}$ & $\begin{array}{r}1480,39 \\
6\end{array}$ & 98 & $\begin{array}{r}15,10 \\
6\end{array}$ & & \\
\hline Total & $\begin{array}{r}1549,71 \\
0\end{array}$ & 99 & & & \\
\hline
\end{tabular}

a. Dependent Variable: Keputusan

Pembelian Konsumen

b. Predictors: (Constant), Physical

Evidence

Sumber : Hasil Pengolahan Data, 2016

Berdasarkan Tabel 4.26 di atas diperoleh nilai $\mathrm{F}_{\text {hitung }}$ sebesar 4,588 $>\mathrm{F}_{0,05}=$ 0,46, dengan nilai signifikant 0.035. Nilai signifikasi tersebut lebih kecil dari taraf signifikansi sebesar 0,05 atau 5\% maka variabel facility eksterior,facility interior, dan other tangible secara simultan berpengaruh terhadap keputusan pembelian konsumen.

\section{Pengujian Hipotesis Secara Parsial (Uji t )}

Uji statistik $\mathrm{t}$ digunakan untuk menunjukkan seberapa jauh pengaruh satu variabel independen secara individual dalam menerangkan variabel dependen. Pengujian dilakukan dengan menggunakan tingkat signifikansi $0,05(\alpha=5 \%)$.

TABEL

\section{Coefficients $^{\mathrm{a}}$}

\section{Hasil Uji Statistik t}

\begin{tabular}{|c|c|c|c|c|c|}
\hline \multirow[b]{2}{*}{ Model } & \multicolumn{2}{|c|}{$\begin{array}{l}\text { Unstandard } \\
\text { ized } \\
\text { Coefficient } \\
\text { s } \\
\end{array}$} & $\begin{array}{c}\text { Standardize } \\
\mathrm{d} \\
\text { Coefficient } \\
\mathrm{s} \\
\end{array}$ & \multirow[b]{2}{*}{$\mathrm{T}$} & \multirow[b]{2}{*}{ Sig. } \\
\hline & B & $\begin{array}{l}\text { Std } \\
\text { Err } \\
\text { or }\end{array}$ & Beta & & \\
\hline $\begin{array}{l}\text { (Consta } \\
\text { nt) }\end{array}$ & $\begin{array}{r}20,71 \\
9\end{array}$ & $\begin{array}{r}3,1 \\
55\end{array}$ & & $\begin{array}{r}6, \\
56 \\
7\end{array}$ & $\begin{array}{r}, 00 \\
0\end{array}$ \\
\hline $\begin{array}{l}\text { Facility } \\
\text { Eksteri }\end{array}$ & 136 &, 14 & 112 & $\begin{array}{r}2, \\
94\end{array}$ & ,34 \\
\hline or & & 4 & & 5 & 7 \\
\hline $\begin{array}{l}\text { Facility } \\
\text { Interior }\end{array}$ &, 056 & $\begin{array}{r}, 08 \\
0\end{array}$ & ,096 & $\begin{array}{r}2, \\
69 \\
9\end{array}$ & $\begin{array}{r}, 48 \\
6\end{array}$ \\
\hline $\begin{array}{l}\text { Other } \\
\text { Tangibl } \\
\text { e }\end{array}$ & ,084 & $\begin{array}{r}20 \\
9\end{array}$ &, 051 & $\begin{array}{r}3, \\
40 \\
2\end{array}$ & $\begin{array}{r}, 68 \\
9\end{array}$ \\
\hline
\end{tabular}


Sumber: Pengolahan data, 2014

Terdapat nilai Sig. 0,347. Nilai Sig. Lebih besar dari nilai probabilitas 0,05, atau nilai $0,347>0,05$, maka $\mathrm{H}_{01}$ ditolak $\mathrm{H}_{\mathrm{a} 1}$ diterima Variabel facility eksterior mempunyai $t_{\text {hitung }}$ yakni 2,945.dengan $t_{\text {tabel }}=1,66055$. Jadi, $t_{\text {hitung }}>t_{\text {tabel }}$ Nilai $t$ positif menunjukkan bahwa variabel facility eksterior mempunyai hubungan yang searah terhadap keputusan pembelian konsumen. Jadi dapat disimpulkan memiliki pengaruh positif yang signifikan terhadap CL.

Variabel facility interior mempunyai $t_{\text {hitung }}$ yakni 2,699 dengan $t_{\text {tabel }}=1,66055$. Jadi, $t_{\text {hitung }}>t_{\text {tabel. }}$. Terdapat nilai Sig. 0,487 Nilai Sig. Lebih besar dari nilai probabilitas 0,05 , atau nilai $0,487>0,05$, maka $\mathrm{H}_{02}$ ditolak dan $\mathrm{H}_{\mathrm{a} 2}$ diterima. maka dapat disimpulkan bahwa secara parsial variabel facility interior memiliki kontribusi yang signifikan terhadap keputusan pembelian konsumen. Jadi dapat disimpulkan facility interior memiliki pengaruh positif yang signifikan terhadap keputusan pembelian konsumen.

Variabel other tangible mempunyai $t_{\text {hitung }}$ yakni 3,402 dengan $t_{\text {tabel }}=1,66055$. Jadi, $t_{\text {hitung }}>t_{\text {tabel. }}$. Terdapat nilai Sig. 0,689 Nilai Sig. Lebih besar dari nilai probabilitas 0,05 , atau nilai $0,689>0,05$, maka $\mathrm{H}_{03}$ ditolak dan $\mathrm{H}_{\mathrm{a}}$ diterima. maka dapat disimpulkan bahwa secara parsial other tangible interior memiliki kontribusi yang signifikan terhadap keputusan pembelian konsumen. Jadi dapat disimpulkan other tangible memiliki pengaruh positif yang signifikan terhadap keputusan pembelian konsumen.

\section{Implikasi Temuan Penetlitian Bersifat Empiris}

Berdasarkan hasil penelitian pengaruh Physical Evidence terhadap Keputusan Pembelian Konsumen, diperoleh temuan yang secara empiris sebagai berikut:

1. Physical Evidence yang dilakukan berpengaruh terhadap keputusan pembelian konsumen. Dimana Physical Evidence merupakan salah satu hal yang cukup penting untuk meningkatkan keputusan pembelian konsumen Happy Cow Steak Palasari Bandung. Physical Evidence secara simultan memiliki pengaruh yang positif terhadap peningkatan keputusan pembelian konsumen Happy Cow Steak Palasari Bandung.

2. Facility Eksterior pada physical evidence memiliki pengaruh yang signifikan terhadap keputusan pembelian konsumen Happy Cow Steak Palasari Bandung dan memiliki penilaian tertinggi pada hasil rekapitulasi tanggapan tamu reguler mengenai physical evidence. Hal ini dikarenakan tanggapan baik konsumen mengenai facility eksterior muncul dari persepsi konsumen yang merasakan kenyamanan serta keamanan pada facility eksterior di Happy Cow Steak Palasari Bandung. Sedangkan penilaian terendah ada pada variabel facility interior. Hal ini dikarenakan konsumen yang makan di Happy Cow Steak Palasari Bandung kurang merasakan kenyamanan fasilitas interior yang ada di Happy Cow Steak Palasari Bandung.

3. Hasil temuan dari penelitian ini tidak hanya menghasilkan pemahaman mengenai keputusan pembelian konsumen, tapi juga cara untuk meningkatkan physical evidence yang lebih baik yang dilaksanakan oleh Happy Cow Steak Palasari Bandung. 


\section{KESIMPULAN}

Berdasarkan uraian-uraian teori, hasil penelitian, dan pengujian analisis regresi ganda yang dilaksanakan mengenai physical evidence terhadap keputusan pembelian konsumen di Happy Cow Steak Palasari Bandung Bandung dapat disimpulkan sebagai berikut:

1. Berdasarkan hasil penelitian diketahui bahwa physical evidence yang dimiliki Happy Cow Steak Palasari Bandung berada cukup baik. Hal ini ditunjukan dengan jawaban responden terhadap kuisioner variabel physical evidence. Penilaian tertinggi berada pada sub variabel fasility eksterior dengan tanggapan menurut reponden bahwa tingkat kenyaman serta keamanan lingkungan sekitar merupakan salah satu faktor yang bisa mendorong keputusan pembelian. Sedangkan penilaian terendah ada pada sub variabel facility interior. Hal ini disebabkan karena tanggapan yang kurang baik tamu terhadap kenyamanan fasilitas interior seperti toilet, playgroud, tamanan hias yang kuran terawat, cat yang mulai kusam.

2. Keputusan pembelian konsumen Happy Cow Steak Palasari Bandung pada kategori cukup baik. Skor tertinggi terhadap keputusan pembelian konsumen terdapat dari pemilihan produk. Responden menyetujui bahwa mereka melakukan pembelian berdasarkan pemilihan produk yang baik. Sedangkan skor terendah ada pada sub variabel pemilihan jumlah pembelian.

3. Hasil penelitian ini menemukan bahwa dari hasil analisis terdapat pengaruh yang positif antara physical evidence terhadap keputusan pembelian konsumen. Secara simultan sub variabel physical evidence yang terdiri dari facility eksterior, facility interior, dan other tangible berpengaruh terhadap keputusan pembelian konsumen. Sedangkan secara parsial sub variabel yang memiliki tingkat signifikan paling tinggi terhadap keputusan pembelian adalah sub variabel facility eksterior. Sedangkan sub variabel yang tingkat signifikannya masih rendah adalah sub variabel facility interior.

\section{DAFTAR PUSTAKA}

Fandy, Tjiptono.(2006). Pemasaran Jasa. Malang: Bayumedia

Michele Caroline Van Der Merwe. (2006). Marketing Communication Methods Used By Tour Operators In Gauteng, pp. 67-68.

Ratih ,Huriyati. (2008). Bauran Pemasaran dan Loyalitas Konsumen. Bandung: Alfabeta

Sugiyono. (2010). Metode Penelitian Bisnis. Bandung: Alfabeta

Yazid. (2008). Pemasaran Jasa dan Konsep Implementasi. Ekonosia FE VIII.

Zeithaml, V.A., m.j. Bitner.(2013) Service Marketing: Integrating Customer Focus Across the Firm $6^{\text {th }}$ ed. Mc-Graw Hill. Boston.

Skripsi :

Riska Putri Amalia. 2012, Pengaruh Physical Evidence Objek Wisata Pemandian Air Panas Ciwalini Terhadap Keputusan Berkunjung Wisatawan. Skripsi UPI : Tidak diterbitkan 